Working Paper No. 2012/50

\title{
Can Cities or Towns Drive African Development? Economy-wide Analysis for Ethiopia and Uganda
}

\author{
Paul Dorosh, ${ }^{1}$ and James Thurlow ${ }^{2}$
}

May 2012

\begin{abstract}
Rapid urbanization is an important characteristic of African development and yet the structural transformation debate focuses on agriculture's relative merits without also considering the benefits from urban agglomeration. As a result, African governments are often provided conflicting recommendations on the importance of rural agriculture or urban industry. We develop dynamic economy-wide models for Ethiopia and Uganda that capture both traditional aspects of the debate (growth linkages and foreign trade) and benefits from urbanization (internal migration and agglomeration effects). Simulations suggest that urban agglomeration is an important source of long-term growth and structural transformation, but that investing in cities does not greatly reduce national poverty over the short-term. In this regard, agricultural growth is more effective, albeit with slower national growth. Given these trade-offs, we conclude that

Keywords: urbanization, rural development, growth, poverty, CGE model, Africa

JEL classification: D58, O18, R11, R23

Copyright (C) UNU-WIDER 2012

${ }^{1}$ International Food Policy Research Institute, Washington DC; ${ }^{2}$ (corresponding author) UNU-WIDER, Helsinki, email: thurlow@wider.unu.edu

This study has been prepared within the UNU-WIDER project 'New Directions in Development Economics'.

UNU-WIDER acknowledges the financial contributions to the research programme by the governments of Denmark (Ministry of Foreign Affairs), Finland (Ministry for Foreign Affairs), Sweden (Swedish International Development Cooperation Agency-Sida) and the United Kingdom (Department for International Development).
\end{abstract}

ISSN 1798-7237

ISBN 978-92-9230-513-0 
the urbanization's benefits argue against an 'agro-fundamentalist' approach to African development, but the short-term imperative of reducing poverty necessitates further agricultural investment.

\section{Acronyms}

CEF constant elasticity of transformation function

CES constant elasticity of substitution function

CPI consumer price index

GDP gross domestic product

SAM social accounting matrix

TFP total factor productivity

UBOS Uganda Bureau of Statistics

The World Institute for Development Economics Research (WIDER) was established by the United Nations University (UNU) as its first research and training centre and started work in Helsinki, Finland in 1985. The Institute undertakes applied research and policy analysis on structural changes affecting the developing and transitional economies, provides a forum for the advocacy of policies leading to robust, equitable and environmentally sustainable growth, and promotes capacity strengthening and training in the field of economic and social policy making. Work is carried out by staff researchers and visiting scholars in Helsinki and through networks of collaborating scholars and institutions around the world.

www.wider.unu.edu publications@wider.unu.edu

UNU World Institute for Development Economics Research (UNU-WIDER)

Katajanokanlaituri 6 B, 00160 Helsinki, Finland

Typescript prepared by Liisa Roponen at UNU-WIDER

The views expressed in this publication are those of the author(s). Publication does not imply endorsement by the Institute or the United Nations University, nor by the programme/project sponsors, of any of the views expressed. 


\section{Introduction}

The relative importance of agriculture versus industry in African development remains a major area of debate (Gollen 2010; Diao, Hazell and Thurlow 2010; Hazell et al. 2010; Collier and Dercon 2012). This debate is crucial since it informs the allocation of foreign development assistance across rural areas, towns and cities at a time when Africa is rapidly urbanizing. The subject of the debate is also crucial for African governments who routinely allocate scarce resources across competing development objectives. For example, Uganda's government must decide how best to reallocate resources away from southern regions towards post-conflict northern cities and rural areas (Dorosh and Thurlow 2011). Similarly, Ethiopia's government limits urban migration through its land tenure policies, but must weigh this policy against the benefits of urban development (see de Brauw and Mueller 2012).

At its broadest level, the academic debate hinges on whether the traditional development models that sought to explain the drivers and process of structural transformation are still relevant for Africa. Early dual economy models viewed nonagriculture as the dynamic sector that draws surplus farm workers into more productive jobs (see, for example, Lewis 1954). Agricultural growth was seen as necessary to prevent rising food prices and wages from slowing industrialization. Subsequent models attributed a more active role to agriculture given its industrial production linkages (Johnson and Mellor 1961) and its household consumption linkages, particularly within rural economies (Adelman 1984; Haggblade, Hazell and Brown 1989). For those who Gollin (2010) terms 'agro-fundamentalists', these models still provide the core justification for an agriculture-led growth strategy in Africa. Agriculture is also seen as a direct link to poorer Africans given their dependence on farm-based livelihoods (Diao, Hazell and Thurlow 2010).

The traditional models face two major criticisms. First, integrated global markets mean that countries might be able to use food imports rather than domestic production to support industrialization. Second, the sources of growth are not explicitly identified in traditional models making it difficult to determine which sectors drive structural transformation. In this regard, African agriculture has yet to demonstrate that it is able to generate productivity gains like those experienced in Asia's green revolution. Counter-arguments contend that a reliance on food imports would weaken inter-sectoral growth linkages and widen the rural-urban divide (Hazell et al. 2010). Moreover, African agriculture's historically poor performance might reflect long-term underinvestment in the sector rather than its growth potential.

The above arguments focus on agriculture itself and are well-trodden areas of the debate. An area that receives less attention is the benefits from urban agglomeration economies and the growing interest in new economic geography (see Fujita, Krugman and Venables 2001). From this perspective, economic growth accelerates when resources or activities concentrate within geographic areas (Henderson and Wang 2005). Urbanization and industrial localization can generate positive externalities by situating producers closer to labour markets and customers, as well as to each other. Urban agglomeration could therefore generate the productivity gains required to drive structural transformation. Agglomeration economies were not explicitly considered in traditional models and so might provide an additional argument in favour of directing resources towards industries in major cities and towns (see World Bank 2008). 
In this paper we examine whether urban agglomeration economies significantly alter the debate over the potential drivers of Africa's structural transformation. More specifically, we develop an economy-wide model that captures the benefits from urbanization. Unlike most models, ours distinguishes between rural areas, small towns and major cities, and allows for internal migration and urban agglomeration effects. It captures rural-urban production and consumption linkages as well as international trade, thereby incorporating many of the arguments in favour or against agriculture. We calibrate the models to data for Ethiopia and Uganda--two agriculture-based African countries where urban development is central to the policy debate.

The models are used to simulate the effects of accelerated urbanization, and the growth and poverty impacts (and trade-offs) of reallocating public investment between rural areas, towns and major cities. Our results suggest that urbanization and agglomeration economies are important sources of economic growth and might well be a driver of long-term structural transformation in Africa. However, over the short-term, investing in major cities does little to address national poverty. Agricultural growth is found to be a more effective means of reaching the poor, albeit at the cost of slower national growth. Given these trade-offs, we conclude that while urban agglomeration does provide an argument against an 'agro-fundamentalist' approach to African development, the shorter-term political and socioeconomic imperative of reducing poverty supports further investment in African agriculture.

The paper is structured as follows: We first outline the economic structure of the two case study countries (Section 2) and their rural and urban economies (Section 3). We then describe the economy-wide model (Section 4) and our simulations and results (Section 5). The final section summarizes our findings.

\section{Ethiopia and Uganda case studies}

Ethiopia and Uganda have characteristics similar to many low-income countries in subSaharan Africa. Both have agriculture-based economies, with agriculture generating roughly half of Ethiopia's gross domestic product (GDP) and a quarter of Ugandan GDP (see Section 3). Despite this difference, about four-fifths of both countries' populations are rural smallholder farmers. Agriculture is also the chief export earner, thus underscoring its importance for both rural and national incomes.

Industries' contribution to national GDP is twice as large in Uganda than in Ethiopia. However, like much of Africa, neither country has a large manufacturing base (about 10 per cent of GDP in Uganda), and most manufacturing is agriculture-related. The remaining industry is mainly construction, with mining currently playing a minor role. 1 Like most African countries, services form the bulk of the non-agricultural economies, primarily non-tradable public services and retail trade.

1 Uganda's recently discovered oil reserves will increase mining's contribution. Mining is usually an enclave sector with few direct benefits for rural and urban economies. It will generate public revenues, which, depending on how they are spent, may affect rural and urban economies differently (see Wiebelt et al. 2011). 
National GDP per capita is twice as large in Uganda, i.e., US\$295 in 2009 compared to US\$151 in Ethiopia (World Bank 2011). 2 This is due to Uganda's larger non-farm economy. In fact, agriculture generates similar value-added per capita in both countries (i.e., about US\$70 per year). Economic growth has been equally rapid in our case studies at 7 per cent per year during 1995-2009. Industry expanded faster than agriculture in both countries, albeit from a low base, causing agriculture's share of GDP to fall. National poverty rates have also fallen: by a third in Ethiopia and a half in Uganda (World Bank 2011). 3 Moreover, while total populations grew at 2.7 and 3.2 per cent each year in Ethiopia and Uganda, respectively, urban populations grew more rapidly at 4.3 and 4.1 per cent.

The economic structures and trends of our case studies are broadly consistent with subSaharan Africa as a whole. Modest industrialization has been accompanied by urbanization, but with little evidence to suggest that economic transformation is taking place (see McMillan and Rodrik 2012). There is also a gradual urbanization of poverty (Ravallion, Chen and Sangraula 2007). The share of the poor population living in Uganda's urban areas rose from 3.4 to 4.8 per cent during 2000-09, while in Ethiopia it rose from 10.1 to 14.3 per cent during 1995-2004 (World Bank 2011). Rising urban poverty might justify greater investment in urban areas. However, as Lipton (1980) and other studies argue, migrants can be 'pushed' by poor agricultural conditions rather than 'pulled' by new urban job opportunities, and so urban investments might treat the symptoms of urban poverty rather than the cause.

Concerns about rising urban poverty are reflected in national policy debates. It has underpinned a land tenure policy in Ethiopia that discourages internal migration (and hence urbanization) by limiting the transferability of land rights between migrants and non-migrants (see de Brauw and Mueller 2012). Land tenure is less of a concern in Uganda (Baland et al. 2007), where the policy debate has focused more on whether the national development plan should emphasize economic growth in the capital city or in smaller towns (see Dorosh and Thurlow 2011). This is especially pertinent given that northern Ugandan towns have lagged behind the rest of the economy, partly as a result of civil conflict. Both Ethiopia and Uganda therefore face trade-offs between investing their scarce public resources in rural agriculture or urban industry, and for the latter, in smaller towns and larger cities.

\section{Distinguishing cities, towns and rural areas}

To examine the growth and poverty impacts of spatially-targeted investments, we separate Ethiopia and Uganda into three sub-national areas, namely cities, towns, and rural areas. We follow the same approach in both countries. We first identify rural areas based on the countries' official 'urban' definitions. 4 Urban areas are then divided into

2 Not adjusted for differences in purchasing power.

3 Based on a US\$1.25 a day poverty line and measured during 1995-2005 and 1996-2009 for Ethiopia and Uganda, respectively.

4 Urban definitions vary across countries. 'Urban' in Ethiopia includes localities of 2000 or more inhabitants, whereas in Uganda there is no absolute population threshold, but rather a registry of cities, municipalities and towns. 
'cities' and 'towns' using population census data (CSA 2007; UBOS 2002a). We define cities as having more than 250,000 inhabitants. They include capital cities, i.e., Addis Ababa and Kampala, and large urban centres, i.e., Dire Dawa and Harar in Ethiopia, and Entebbe and Mukono in Uganda. In 2005, cities accounted for 3.6 and 1.7 million people out of Ethiopia and Uganda's total populations of 71.0 and 27.2 million, respectively (see Table 1 ). The remaining urban areas were classified as 'towns' and contain around 10 per cent of the population.

In order to capture economic linkages between rural and urban areas, we disaggregate each country's individual sectors and households across cities, towns and rural areas. We start from the representation of each economy contained in their national social accounting matrices (SAMs) (EDRI 2009; Thurlow, Diao and Zhu 2007). These economy-wide databases capture all income and expenditure flows between producers, households, and government and foreign sectors within a consistent accounting framework. We use nationally-representative industrial and household surveys to disaggregate national production and employment, and household incomes and expenditures across the three sub-national areas (CSA 2006, 2009; UBOS 2002b, 2006). 5

Table 1

Characteristics of cities, towns and rural areas in Ethiopia and Uganda, 2005

\begin{tabular}{|c|c|c|c|c|c|c|c|c|}
\hline & \multicolumn{4}{|c|}{ Ethiopia } & \multicolumn{4}{|c|}{ Uganda } \\
\hline & Rural & Towns & Cities & All & Rural & Towns & Cities & All \\
\hline Population (mil.) & 60.3 & 7.1 & 3.6 & 71.0 & 23.0 & 2.5 & 1.7 & 27.2 \\
\hline Share (\%) & 84.9 & 10.0 & 5.1 & 100.0 & 84.7 & 9.3 & 6.1 & 100.0 \\
\hline Poor population (mil.) & 25.2 & 2.5 & 0.7 & 28.4 & 10.2 & 0.6 & 0.1 & 10.9 \\
\hline Share (\%) & 88.7 & 8.9 & 2.5 & 100.0 & 93.8 & 5.5 & 0.7 & 100.0 \\
\hline National GDP shares (\%) & 53.3 & 26.4 & 20.4 & 100.0 & 62.4 & 18.0 & 19.6 & 100.0 \\
\hline Regional GDP shares (\%) & 100.0 & 100.0 & 100.0 & 100.0 & 100.0 & 100.0 & 100.0 & 100.0 \\
\hline Agriculture & 81.4 & 17.9 & 0.0 & 48.1 & 37.2 & 5.3 & 0.1 & 24.2 \\
\hline Industry & 3.2 & 15.7 & 27.6 & 11.5 & 18.0 & 30.5 & 36.2 & 23.8 \\
\hline Services & 15.3 & 66.4 & 72.4 & 40.4 & 44.8 & 64.2 & 63.7 & 52.0 \\
\hline Workers (mil.) & 22.3 & 2.6 & 1.3 & 26.2 & 9.5 & 1.1 & 0.7 & 11.3 \\
\hline Skilled & 0.1 & 0.4 & 0.2 & 0.7 & 0.3 & 0.1 & 0.1 & 0.5 \\
\hline Semi-skilled & 0.9 & 1.2 & 0.8 & 2.9 & 1.5 & 0.4 & 0.4 & 2.4 \\
\hline Unskilled & 21.2 & 1.0 & 0.4 & 22.6 & 7.7 & 0.5 & 0.2 & 8.4 \\
\hline
\end{tabular}

Notes: Population from household surveys. Poor population based on national poverty lines set at the $40^{\text {th }}$ population percentile per capita expenditure level. Workers are separated into occupation groups (see footnote 6).

Source: Own calculations using sub-national SAMs (see Section 3).

5 Concerns are sometimes raised about the accuracy of SAMs (see, for example, Collier and Dercon 2012). Our SAMs are based on new input-output tables (i.e., 2005/06 in Ethiopia and 2002/03 in Uganda) built using nationally-representative household and industrial surveys, and were used to rebase national accounts. A major advantage of using SAMs rather than household surveys (as in Ravallion and Datt 1996) is that the latter do not cover crucial areas of our two economies (e.g., private enterprises and government), and often exclude high-income earners from their samples. Our SAMs reconcile multiple data sources to triangulate actual economy-wide structures. 
The more detailed sub-national SAMs indicate that, while rural areas contain 85 per cent of Ethiopia and Uganda's total populations, they account for only 53 and 62 per cent of national GDP, respectively (see Table 1). Per capita household consumption in rural areas is therefore below the national average, which explains the disproportionate share of the poor population living in rural areas. Agriculture is concentrated in rural areas, with an underrepresentation of industry and services compared to the overall economy. Accordingly, there is a larger concentration of unskilled farm workers in rural areas.

Towns contain around 10 per cent of the population, but contribute 26 and 18 per cent to national GDP in Ethiopia and Uganda, respectively. Average per capita consumption in towns is therefore well above the rural average (by more than four times in Ethiopia). Even though some agricultural production occurs within town boundaries, it is the industrial and service sectors that are most important. Accordingly, of the 10 per cent of the national labourforce that works in towns, most have either skilled or semi-skilled occupations. 6

Finally, cities form the economic core of both economies. They contain 5 per cent of the population, but generate a fifth of national GDP. Average per capita consumption is highest in the cities and is many times larger than average rural consumption. This reflects the wide rural and urban divide. Industry and formal services are overwhelmingly concentrated in cities. In the next section we develop economic models that draw on the information contained in these detailed sub-national SAMs, thereby allowing us to represent the unique spatial structures of Ethiopia and Uganda's economies.

\section{Economy-wide models}

We develop economy-wide models for Ethiopia and Uganda that incorporate the main elements of the traditional 'agriculture debate' (i.e., growth linkages and international trade) as well as the benefits from urbanization and agglomeration economies. We briefly describe the main features of the model, and its data sources. A detailed specification is provided in the appendix.

\subsection{Model description}

Our model falls into the 'recursive dynamic computable general equilibrium' (CGE) class of models. Figure 1 offers a stylized representation. Based on the SAMs, we separate each economy into three regions: rural areas, small towns and major cities. Each region contains up to 60 different sectors and has its own production technologies and endowments (i.e., factors and intermediate requirements). Labour markets are segmented into skilled (e.g., managers), semi-skilled (e.g., technicians) and unskilled workers (e.g., farmers). By assumption, rural unskilled labour is underemployed, which is consistent with traditional 'surplus labour' models (see Lewis 1954). In contrast,

6 Workers separated according to occupations. Skilled workers include managers and professionals (International Labour Organization codes 1-2); semi-skilled workers include technicians and retail traders (codes 3-8, excluding 6.2) and unskilled include elementary occupations and subsistence farmers (codes 9 and 6.2). 
agriculture uses crop land as well as labour and capital, and this constrains agriculture's supply response since total land supply grows slowly over time. This is consistent with Ethiopia and Uganda's land constraints and rising population-land ratios. ${ }^{7}$

Figure 1

Regional modelling framework

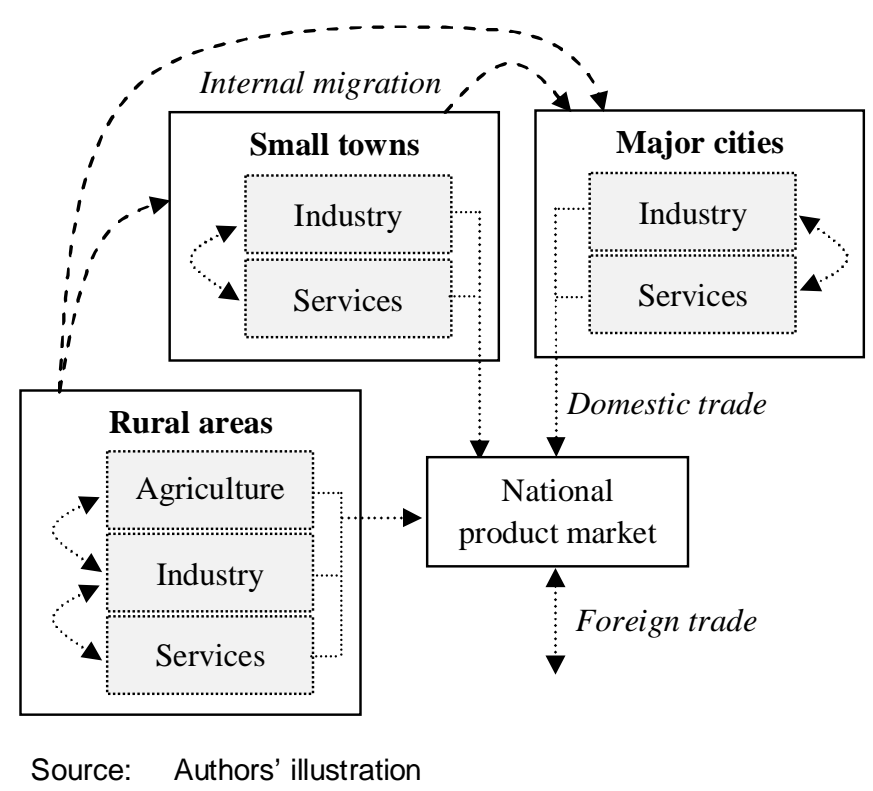

Producers in each region and sector are represented by production functions. Data on internal trade flows are unavailable and so we assume that producers supply national product markets, where a single price equates demand and supply. Certain services are, however, treated as regional non-tradables, such as construction and retail trade, thus capturing some rural farm-nonfarm linkages (see Haggblade, Hazell and Brown 1989). International trade is permitted in the model, although domestic and foreign goods are imperfect substitutes and world prices are fixed. This allows our countries to import food rather than rely on domestic production.

Internal migration is permitted in the model. Workers can only migrate across sectors within a given time period. Between periods they can also migrate across regions in response to wage differentials. Migration rates are initially calibrated so as to replicate observed migrant flows at prevailing wage gaps. 8 Over time, widening wage gaps lead to larger-than-observed migration flows. A region's total labour supply depends on previous period supplies; exogenous population growth; and net internal migration. Workers migrate with their family and can send remittances home, although we assume that households in the sending region are equally likely recipients.

Investment is equal to the sum of all savings less the fiscal deficit, which is the different between the government's tax revenues and recurrent spending. New capital stocks depend on previous period investment, and are allocated to regions and sectors

7 Multiplier models assume unlimited factor supplies and so, unlike CGE models, do not capture resource constraints. This distinction is sometimes overlooked or misunderstood.

8 Observed migration rates and flows are based on population census data (CSA 2007; UBOS 2002a). 
according to profit differentials. Once invested, capital cannot move between sectors and regions. Migration tends to raise the returns to capital in destination regions, and so urbanization can attract larger allocations of new capital and so cause faster economic growth in cities and towns.

Urbanization also affects the rate of technical change or productivity growth in each region. Following Henderson and Wang (2005), we assume that agglomeration spillovers are a positive function of population density. As workers move to a city or town they raise the population density and hence productivity in all sectors. 9 However, urbanization reduces the amount of public capital available to each urban resident, and, without supporting public investment, reduces productivity gains from urban agglomeration (i.e., 'congestion' effects). The allocation of public capital across rural areas, towns and cities is exogenously determined and is the main policy instrument for our simulations. Finally, given sparse populations in rural areas and the concentration of industry in urban areas, we only allow agglomeration in cities and towns.

In summary, the model includes production and consumption linkages; has underemployed rural unskilled labour; and captures some rural farm-nonfarm linkages. These are the main arguments posited by 'agro-fundamentalists'. On the other side of the debate, the model captures resource constraints; and food import opportunities. More importantly, we include internal migration and urban agglomeration economies, such that urbanization leads to faster productivity growth and allows for greater absorption of rural workers and their families. The model allows us to determine whether cities or towns can become drivers of structural transformation.

\subsection{Data sources}

CGE models are 'semi-empirical' since their variables and parameters are calibrated to country data. Section 3 described how national SAMs for Ethiopia and Uganda were disaggregated across cities, towns and rural areas using industrial and household survey data. These SAMs provide the data needed to calibrate the economic structure of the models to a 2005 benchmark year. Household survey data were used to segment labour markets into skill groups. Substitution elasticities for the production and foreign trade functions cannot be estimated for our case study countries and are therefore based on cross-country estimates from Dimaranan (2006). Finally, households in each area are separated into 'poor' (bottom two per capita expenditure quintiles) and 'non-poor'. Income elasticities were estimated using each country’s household survey and the econometric approach outlined in King and Byerlee (1978).

\section{Simulation results}

The models are used to examine the impact of (i) accelerating rural-to-urban migration (i.e., 'urbanization' scenario); and (ii) reallocating public investment towards cities,

9 The elasticity linking population density to agglomeration effects is set at 0.08 based on estimates by Rosenthal and Strange (2004). It is assumed that sparsely populated rural areas do not experience agglomeration spillovers. 
towns and rural areas (i.e., 'investment' scenarios). We first construct a counterfactual baseline scenario.

\subsection{Baseline growth path}

The baseline scenarios for each country are calibrated to recent economic and demographic trends. We assume that Ethiopia and Uganda's populations grow at 2.5 and 3.0 per cent per year, respectively, during 2005-25 (see Table 2). Labour supply is determined by exogenous trends and by endogenous demand for underemployed unskilled labour in rural areas. The expansion of total labour supply is consistent with population growth (i.e., 2.4 per cent in Ethiopia and 2.9 per cent in Uganda). This means that the national dependency ratio remains fairly constant over time. Rising population density in Ethiopia and Uganda has resulted in greater land scarcity, and this is captured in the model by slower agricultural land expansion. Capital accumulation rates are endogenous. Capital stocks grow faster than labour supply, reflecting more rapid private investment growth and rising capital availability. This is matched by public investment, which grows at 4 per cent per year in both countries. This is faster than population growth and implies that public capital per capita rises in the baseline.

Labour supply growth rates in each area diverge over time due to internal migration. The model endogenously reallocates labour and populations across cities, towns and rural areas. We assume that the 2005 base-year wage differentials reproduce the internal migration flows observed in Ethiopia and Uganda during the late 1990s (see Golini et al. 2001; UBOS 2002a). This implies a net annual inflow of around 25,000 and 7,500 migrants into Ethiopia and Uganda's major cities, respectively. Migrants moving to cities come from either towns or rural areas. Migration from rural areas to towns is larger than to cities, although this is offset by outflows from towns to cities. Net inmigration causes urban population growth to exceed that of rural areas. This is consistent with current urbanization trends in Ethiopia and Uganda. Population growth is faster in towns than cities since new migrants comprise a larger share of towns' workforces each year.

Table 2

Baseline scenario

\begin{tabular}{|c|c|c|c|c|c|c|c|c|}
\hline & \multicolumn{4}{|c|}{ Ethiopia } & \multicolumn{4}{|c|}{ Uganda } \\
\hline & Rural & Towns & Cities & All & Rural & Towns & Cities & All \\
\hline Annual GDP growth (\%) & 3.13 & 5.71 & 8.13 & 5.21 & 3.98 & 6.89 & 9.30 & 5.99 \\
\hline Labour & 2.25 & 3.41 & 2.93 & 2.41 & 2.71 & 3.72 & 3.29 & 2.85 \\
\hline Crop Land & 1.00 & 1.00 & 1.00 & 1.00 & 1.00 & 1.00 & 1.00 & 1.00 \\
\hline Capital & 4.52 & 3.89 & 2.80 & 4.28 & 4.66 & 5.38 & 5.85 & 5.15 \\
\hline TFP & 1.07 & 2.74 & 4.64 & 2.60 & 1.09 & 2.94 & 4.73 & 2.54 \\
\hline Annual migrant flow (1000s) & -91.31 & 66.27 & 25.04 & 0.00 & -25.49 & 17.72 & 7.77 & 0.00 \\
\hline Share of workforce (\%) & -0.33 & 1.69 & 1.35 & 0.00 & -0.25 & 1.34 & 0.97 & 0.00 \\
\hline Population growth rate (\%) & 2.19 & 4.09 & 3.67 & 2.50 & 2.79 & 4.18 & 3.81 & 3.00 \\
\hline
\end{tabular}

Source: CGE modelling results. 
Economic growth in the models is determined by factor supplies and rates of technical change. As described in Section 4, technical change in the model has both endogenous and exogenous components. Urban in-migration endogenously generates positive agglomeration effects, although these are offset by declining per capita public capital (i.e., congestion effects). Exogenous sector productivity growth is set at 1.0 per cent per year for agricultural and rural non-farm producers, and at 2.5 and 4.0 per cent for producers in towns and cities, respectively. This is consistent with observed sector-level growth rates from national accounts. These rates of technical change also capture the faster growth of urban industrial centres in our two case studies. By contrast, agricultural and rural growth is constrained by low productivity growth, declining land availability, and the absence of agglomeration gains. Given the above baseline assumptions, Ethiopia and Uganda's economies expand at 5.2 and 6.0 per cent per year, respectively (see Table 2). Given differences in population growth, this translates into roughly 3 per cent annual GDP per capita growth in each country.

Table 3 decomposes the sources of baseline GDP growth. This is done by initially excluding surplus labour, migration and agglomeration effects from the baseline, and then re-introducing them incrementally into the model. Early development models suggest that economic growth can be achieved by reallocating resources from low productivity agriculture to higher productivity industry. The table indicates that internal migration from rural to urban sectors accounts for 6.1 and 12.2 per cent of total baseline GDP growth in Ethiopia and Uganda, respectively. 10 The difference between countries is because Uganda has greater absorptive capacity for migrants given its larger non-farm economy (see Section 2). Introducing surplus rural labour, as per Lewis' development model, generates a further 3.4 and 2.0 per cent of baseline growth in Ethiopia and Uganda, respectively. Finally, exogenous technical change is an important driver of growth in both countries, indicating that urban agglomeration economies and factor accumulations explain only part of recent growth performances. However, agglomeration accounts for around 10 per cent of growth. Agglomeration gains are smaller in Ethiopia due to the country's larger rural farm economy, where agglomeration effects are assumed not to exist.

Table 3

Sources of baseline growth

\begin{tabular}{lcc}
\hline & Ethiopia & Uganda \\
\hline Total GDP (\%) & 100.0 & 100.0 \\
Exogenous labour supply & 12.4 & 17.7 \\
Surplus labour supply & 3.4 & 2.0 \\
Capital accumulation & 27.4 & 21.1 \\
Exogenous TFP growth & 42.7 & 34.5 \\
Internal migration & 6.1 & 12.2 \\
Agglomeration effects & 8.1 & 12.5 \\
\hline Notes: 'Internal migration' does not include the agglomeration \\
$\quad$ effects caused by urban in-migration, which is included \\
$\quad$ under 'agglomeration effects'. \\
Source: CGE modelling results.
\end{tabular}

10 Urbanization's contribution to total economic growth includes the effects of increased urban labour supplies, faster urban capital accumulation, and agglomeration and congestion effects. 
Our baseline scenarios are consistent with Ethiopia and Uganda's long-term growth performances. Based on observed rural-urban migration rates, both countries continue to urbanize, with the urban population shares rising from about 15 per cent in 2005 to about 20 per cent in 2025. Agriculture's poorer performance relative to industry and services reduces its contribution to national GDP. This reflects the slow ongoing process of structural transformation out of agriculture. This gives rise to the observed widening rural-urban divide in our two case country cases.

\subsection{Accelerating urbanization}

Numerous studies have examined migration behaviour in low-income countries (see Lucas 1997). They find that an individual's decision to migrate is influenced by a number of factors, including their education levels, social networks and job search costs. As mentioned earlier, land tenure policies also restrict migration in Ethiopia. In the first set of simulations we explore the implications of increasing rural-to-urban migration rates (i.e., above the historically observed baseline rates). The models then trace through the economic implications of more rapid urbanization on economic growth and household welfare.

The urban population share rose to around 20 per cent in the baseline scenario. We increase this by a further ten percentage points in the urbanization scenario, thus bringing Ethiopia and Uganda closer to the average for sub-Saharan Africa (World Bank 2011). The second column in Table 4 reports wage differentials and migration flows for the urbanization scenario. The larger flow of migrants into urban areas increases job competition in urban sectors, causing the ratio of average urban wages to average rural wages to fall. For example, in Ethiopia, urban workers at the end of the baseline scenario (i.e., in 2025) earned, on average, six times more than rural workers.

Table 4

Wage differentials and migration flows, 2005-25

\begin{tabular}{|c|c|c|c|c|c|}
\hline & \multirow{2}{*}{$\begin{array}{l}\text { Baseline } \\
\text { scenario }\end{array}$} & \multirow{2}{*}{ Urbanization } & \multicolumn{3}{|c|}{ Investment scenarios } \\
\hline & & & Cities & Towns & Rural \\
\hline & & Ethiopia & & & \\
\hline \multicolumn{6}{|c|}{ Average wage ratios, 2025} \\
\hline Towns / rural areas & 3.14 & 2.24 & 3.10 & 3.13 & 3.21 \\
\hline Cities / rural areas & 6.02 & 4.24 & 6.06 & 5.98 & 6.08 \\
\hline Cities / towns & 1.92 & 1.90 & 1.96 & 1.91 & 1.89 \\
\hline \multicolumn{6}{|c|}{ Annual migrant flows (1000s) } \\
\hline Rural areas & -91.3 & -263.9 & -89.9 & -90.7 & -96.7 \\
\hline Towns & 66.3 & 153.8 & 64.3 & 65.6 & 71.9 \\
\hline \multirow[t]{2}{*}{ Cities } & 25.0 & 110.1 & 25.6 & 25.2 & 24.8 \\
\hline & & Uganda & & & \\
\hline \multicolumn{6}{|c|}{ Average wage ratios, 2025} \\
\hline Towns / rural areas & 3.64 & 2.90 & 3.66 & 3.72 & 3.62 \\
\hline Cities / rural areas & 5.05 & 4.32 & 5.17 & 5.10 & 5.04 \\
\hline Cities / towns & 1.39 & 1.49 & 1.41 & 1.37 & 1.39 \\
\hline \multicolumn{6}{|c|}{ Annual migrant flows (1000s) } \\
\hline Rural areas & -25.5 & -98.6 & -25.5 & -25.8 & -25.8 \\
\hline Towns & 17.7 & 64.6 & 17.6 & 18.0 & 17.9 \\
\hline Cities & 7.8 & 34.1 & 7.9 & 7.8 & 7.8 \\
\hline
\end{tabular}


However, the number of new migrants arriving in cities each year rises from 66,300 in the baseline to 153,800 in the urbanization scenario. This causes the city-to-rural wage ratio to fall, such that city workers earn just over four times the rural wage by the end of the urbanization scenario. A similar fall in urban-to-rural wage ratios occurs in Uganda when urbanization accelerates. However, as discussed in Sections 2 and 3, Uganda's industrial and service sectors are far larger than Ethiopia's, and therefore provide more employment opportunities for new migrants from rural areas. Accordingly, the wage ratio falls by less in Uganda, despite a larger percentage increase in the number of ruralto-urban migrants.

More rapid urbanization reduces the total supply of labour in rural areas, despite being able to draw on an underemployed rural workforce. This decline in productive resources places downward pressure on agricultural GDP growth, despite an increase in output per worker. However, urban sectors benefit from increased labour supplies and lower real wages (see Table 5). Faster urban growth generates backward linkages to agriculture, through for example increased demand for raw inputs from downstream food processing. The net effect is a small increase in agricultural GDP growth in both Ethiopia and Uganda. The relative strengths of each country's production linkages explain the differences in outcomes across our two case studies. As mentioned earlier, Uganda's manufacturing sector is twice the size of Ethiopia's, and half of this sector is agro-processing. An expansion of the non-agricultural sector in Uganda therefore generates larger demand for agricultural goods than similar non-agricultural growth in Ethiopia. Moreover, urbanization generates faster industrial GDP growth in Uganda, because dependency ratios are lower in this country, implying that more workers migrate to urban centres in order for the urban population share to reach the targeted 30 per cent.

Table 5

Economic growth results, 2005-2025

\begin{tabular}{|c|c|c|c|c|c|}
\hline & \multirow[b]{3}{*}{ Baseline growth (\%) } & \multicolumn{4}{|c|}{ Deviation from baseline (\%-point) } \\
\hline & & \multirow[b]{2}{*}{ Urbanization } & \multicolumn{3}{|c|}{ Investment scenarios } \\
\hline & & & Cities & Towns & Rural \\
\hline \multicolumn{6}{|c|}{ Ethiopia } \\
\hline Annual GDP growth & 5.21 & 0.59 & 0.23 & 0.19 & -0.19 \\
\hline Agriculture & 2.77 & 0.11 & -0.19 & -0.09 & 0.75 \\
\hline Industry & 7.23 & 1.01 & 0.43 & 0.28 & -0.82 \\
\hline Services & 6.65 & 0.72 & 0.41 & 0.33 & -0.63 \\
\hline Rural areas & 3.13 & 0.16 & -0.13 & -0.07 & 0.63 \\
\hline Towns & 5.71 & 0.40 & 0.13 & 0.53 & -0.65 \\
\hline Cities & 8.13 & 1.15 & 0.67 & 0.18 & -0.80 \\
\hline \multicolumn{6}{|c|}{ Uganda } \\
\hline Annual GDP growth & 5.99 & 1.57 & 0.50 & 0.29 & -0.24 \\
\hline Agriculture & 3.54 & 1.04 & -0.01 & -0.03 & 0.89 \\
\hline Industry & 7.24 & 1.82 & 0.64 & 0.43 & -0.52 \\
\hline Services & 6.65 & 1.80 & 0.66 & 0.36 & -0.54 \\
\hline Rural areas & 3.98 & 0.77 & 0.14 & 0.07 & 0.33 \\
\hline Towns & 6.89 & 1.86 & 0.28 & 0.62 & -0.58 \\
\hline Cities & 9.30 & 2.30 & 1.04 & 0.37 & -0.82 \\
\hline
\end{tabular}

Source: CGE modelling results. 
Increasing the urban population share by ten percentage points raises total GDP growth by 0.6 and 1.6 per cent per year in Uganda and Ethiopia, respectively. Most of this growth is concentrated in cities and towns. Increasing demand from urban consumers causes food prices to rise faster than the consumer price index (CPI). Moreover, faster economic growth in urban areas is offset by in-migration and a larger urban population. Both lead to a decline in urban real incomes. This is reflected in falling household welfare in cities and towns in urbanization scenario (see Table 6). This is based on 'equivalent variation', which is a consumption-based welfare measure that controls for changing prices. In contrast, rural households, particularly farmers, benefit from lower underemployment and higher agricultural prices. Overall, national welfare improves, although the gains are larger for non-poor households. This suggests that the urbanization of relative poverty will continue in Ethiopia and Uganda without supporting investments in urban growth and job creation.

Table 6

Household welfare results, 2005-25

\begin{tabular}{|c|c|c|c|c|c|}
\hline & \multirow{3}{*}{$\begin{array}{l}\text { Baseline } \\
\text { growth (\%) }\end{array}$} & \multicolumn{4}{|c|}{ Deviation from baseline (\%-point) } \\
\hline & & \multirow{2}{*}{ Urbanization } & \multicolumn{3}{|c|}{ Investment scenarios } \\
\hline & & & Cities & Towns & Rural \\
\hline \multicolumn{6}{|c|}{ Ethiopia } \\
\hline Annual welfare change & 1.73 & 0.41 & 0.08 & 0.10 & 0.10 \\
\hline Poor & 1.17 & 0.25 & -0.03 & 0.04 & 0.30 \\
\hline Non-poor & 1.86 & 0.44 & 0.10 & 0.12 & 0.05 \\
\hline Rural areas & 1.38 & 0.90 & -0.02 & 0.04 & 0.30 \\
\hline Towns & 0.72 & -1.22 & 0.14 & 0.19 & -0.14 \\
\hline Cities & 1.69 & -1.95 & 0.29 & 0.15 & -0.22 \\
\hline \multicolumn{6}{|c|}{ Uganda } \\
\hline Annual welfare change & 2.45 & 1.31 & 0.31 & 0.20 & 0.01 \\
\hline Poor & 1.50 & 1.05 & 0.16 & 0.08 & 0.29 \\
\hline Non-poor & 2.59 & 1.35 & 0.33 & 0.21 & -0.03 \\
\hline Rural areas & 1.81 & 1.68 & 0.23 & 0.12 & 0.19 \\
\hline Towns & 2.21 & -0.71 & 0.30 & 0.34 & -0.25 \\
\hline Cities & 3.64 & -0.25 & 0.59 & 0.31 & -0.36 \\
\hline $\begin{array}{l}\text { Welfare measu } \\
\text { for price chang }\end{array}$ & equivalent & tion, which is & sumpt & ed mea & hat controls \\
\hline Source: CGE modelling & & & & & \\
\hline
\end{tabular}

\section{Investing in cities, towns and rural areas}

The allocation of public capital in Ethiopia and Uganda currently favours urban areas. In Ethiopia, for example, rural areas contain 85 per cent of the population but receive only 81.4 per cent of public investment. In contrast, cities contain 5 per cent of the population yet receive 9 per cent of public investment. Our second set of scenarios explores the implications of reallocating these public investments towards cities, towns or rural areas (i.e., without increasing the current level of public investment).

In the first simulation we reallocate 10 per cent of new public capital away from towns and rural areas towards cities (i.e., the 'cities' scenario). Continuing with the Ethiopian 
example, this reallocation raises the public investment share for cities from 9 to 19 per cent, while proportionally reducing the investment in towns and rural areas. This reallocation increases per capita public capital in cities and alleviates some of the baseline's negative congestion effects (i.e., it raises total factor productivity [TFP] growth in cities). However, reducing public investment elsewhere increases congestion in towns and reduces rural agricultural productivity (see below). The second simulation is similar to the first, except that towns, rather than cities, are the recipients of redirected investment (i.e., the 'towns' scenario).

The third simulation allocates 10 per cent of public investment to rural agriculture (i.e., the 'rural' scenario). This increases agriculture's TFP growth rate. We adopt a public agricultural spending to TFP growth elasticity of 0.15 , the point estimated by Benin et al. (2012) using cross-country regressions for 18 African countries. We assume that the government's capital investment is half of total agricultural spending. In Ethiopia, allocating an additional 10 per cent of public investment to agriculture causes rural public capital stocks to increase by 13 per cent per year relative to the baseline. The reallocation therefore increases agriculture's TFP growth rate by one percentage point (i.e., $0.15 \times 13 \times 0.5=0.98$ ). Conversely, a reduction in rural investment, as is the case in the cities and towns scenarios, causes agriculture's TFP growth rate to fall. This is the immediate trade-off between investing in rural and urban sectors in the model, and is the result of a fixed resource envelope. Since the amount of investment in each simulation is identical, and since we account for fiscal constraints, the results of the cities, towns and rural scenarios are directly comparable.

It should be acknowledged that none of the scenarios identify the specific investments needed to generate economic growth. Empirical studies for Ethiopia and Uganda often emphasize infrastructure and social spending (see Fan 2008). However, Africa has a relatively poor track record in targeting specific economic sectors, be they rural agriculture or urban industry. Therefore, while it is possible to model specific investments (see, for example, Thurlow 2012), we purposefully remain focused on the broader structural transformation debate. That being said, there is little reason to expect a priori that, in aggregate, future investments will be more or less effective than the past investments on which our spending elasticities are based.

The final three columns in Table 5 show how reallocating public resources raises GDP growth in recipient areas. For example, in Ethiopia's cities scenario, total GDP growth in cities accelerates by 0.7 per cent per year from a baseline growth rate of 8.1 per cent. Similar accelerations are observed in towns and rural areas in the two other investment scenarios. However, physical and financial resource constraints imply trade-offs between scenarios. For example, when investment is directed towards rural areas it lowers non-agricultural growth, causing total GDP to decline in towns and cities relative to the baseline.

Rural-urban migration is also influenced by the location and sector of public investment. As shown in Table 4, rural out-migration actually increases slightly when agricultural productivity rises, as workers are released to seek employment in urban industrial sectors. This is also due to higher agricultural production, which reduces food prices relative to the CPI, thereby lowering real rural wages (note the increase in the towns-to-rural wage ratio). 
Rural GDP growth falls when investments are directed towards Ethiopia's urban areas (see Table 5). This trade-off is less pronounced in Uganda, where stronger production linkages between agro-processing and agriculture limit the decline in agricultural GDP growth in the cities and towns scenarios. This is sufficient for Uganda's rural economy to benefit from faster overall economic growth. In both countries, investing in cities generates more migration and agglomeration effects and results in the largest gains for national economic growth. Conversely, investing in rural areas causes national economic growth to decelerate relative to the baseline.

Although investing in urban areas favours national economic growth, its benefits for household welfare are less certain (see Table 6). In Ethiopia, national welfare improves in both the cities and towns scenario, but investing in urban areas is less effective in improving the welfare of the poor (i.e., those in the bottom two per capita expenditure quintiles). For example, while the equivalent variation of the non-poor increases by 0.1 per cent per year in Ethiopia's cities scenario (relative to the baseline), the welfare of the poor declines slightly. There is a similar divergence between poor and non-poor outcomes in Uganda's urban investment scenarios. Thus, while increasing urban investment favours economic growth, it reduces the 'inclusiveness' of that growth. By contrast, investing in rural agriculture is more effective at improving the welfare of poorer households, despite slower national economic growth. This is because agriculture directly improves the livelihoods of mainly farm-based poor households, while reducing food prices for rural and urban consumers.

\section{Conclusions}

The development literature often provides conflicting recommendations to African countries. On the one hand, governments are encouraged to direct physical and financial resources towards urban industrialization, in part to harness the agglomeration effects brought about by concentrating economic activity in specific geographic locations. On the other hand, governments have for a long time been told that agriculture has strong growth linkages, both within rural areas and national economies. Investing in agriculture may therefore generate large economy-wide multiplier effects--as is said to have occurred during Asia's green revolution. While urban and rural development are not necessarily mutually exclusive, a scarcity of public resources, and the need to meet both short- and long-term development objectives, implies that trade-offs between rural and urban investments are expected.

To examine these trade-offs, we developed a dynamic economy-wide model. Unlike most other economic models, ours is designed to capture both traditional and new elements of the rural-urban debate, including sub-national growth linkages, food imports, internal migration, and agglomeration and congestion effects. Two instances of the model were calibrated to data for Ethiopia and Uganda, countries that have much in common with the rest of low-income Africa. We used the models to examine the growth and poverty implications of more rapid urbanization, and a reallocation of public resources between cities, towns and rural areas.

Simulation results indicate that urbanization and agglomeration economies are important sources of economic growth and could be drivers of long-term structural transformation in Africa. It also has the potential to reduce the rural-urban divide. This 
is especially true in Uganda, where the industrial sector has stronger linkages to rural agriculture. However, without supporting investments in urban growth and job creation, there is likely to be an 'urbanization of poverty' in both Ethiopia and Uganda. Rising urban poverty could prevent the use of large-scale rural-to-urban transfer programmes aimed at offsetting the decline in agricultural growth from reallocating away from rural areas. As such, our findings suggest that, at least over the short-term, investing in cities is unlikely to adequately address national poverty concerns.

In contrast, agricultural growth is a more direct and effective means of reaching the poor in the short run, but it comes at the cost of slower national growth and with possible long-term implications for the rate of structural transformation. Given these trade-offs, we conclude that while urban agglomeration provides an additional argument against an 'agro-fundamentalist' approach to African development, the shorter-term political and socioeconomic imperative to reduce poverty still supports further investment in African agriculture.

\section{References}

Adelman, I. (1984). 'Beyond Export-Led Growth’. World Development, 12(9): 937-49.

Armington, P. A. (1969). 'A Theory of Demand for Products Distinguished by Place of Production. IMF Staff Papers, 16(1): 159-78.

Baland, J., F. Gaspart, E. Place, and J. Platteau (2007). 'The Distributive Impact of Land Markets in Uganda'. Economic Development and Cultural Change, 55(2): 283-312.

Benin, S., S. Fan, and M. Johnson (2012). 'Estimating Public Agricultural Expenditure Requirements'. In X. Diao, J. Thurlow, S. Benin and S. Fan (eds), Strategies and Priorities for African Agriculture: Economy-wide Perspectives from Country Studies. Washington DC: IFPRI.

CSA (Central Statistical Agency). (2006). Household Income, Consumption and Expenditure Survey 2004/05. Addis Ababa: Federal Democratic Republic of Ethiopia.

CSA (2007). Population and Housing Census 2007. Addis Ababa: Federal Democratic Republic of Ethiopia.

CSA (2009). Large and Medium Manufacturing Industries Survey 2007-2008. Addis Ababa: Federal Democratic Republic of Ethiopia.

Collier, P., and S. Dercon (2012). 'African Agriculture in 50 Years: Smallholders in a Rapidly Changing World’. Washington, DC: International Food Policy Research Institute. Unpublished manuscript.

De Brauw, A., and V. Mueller (2012). 'Do Limitations in Land Rights Transferability Influence Mobility Rates in Ethiopia?'. Washington, DC: International Food Policy Research Institute. Unpublished manuscript.

Dervis, K., J. De Melo, and S. Robinson (1982). General Equilibrium Models for Development Policy. New York: Cambridge University Press. 
Diao, X., P Hazell, and J. Thurlow (2010). he Role of Agriculture in African Development'. World Development, 38(10): 1375-83.

Dimaranan, B. (ed.) (2006). Global trade, assistance and production: The GTAP 6 data base. West Lafayette, IN: Center for Global Trade Analysis, Purdue University.

Dorosh, P., and J. Thurlow (2011). 'Agglomeration, Growth and Regional Equity: An Analysis of Agriculture versus Urban-led Development in Uganda'. Journal of African Economies. doi:10.1093/jae/ejr033>

EDRI (Ethiopian Development Research Institute) (2009). Input Output Table and Social Accounting Matrix. Addis Ababa: EDRI.

Fan, S. (ed.) (2008). Public Expenditures, Growth, and Poverty: Lessons from Developing Countries. Baltimore, MD: Johns Hopkins University Press.

Fujita, M., P. Krugman, and A. J. Venables (2001). The Spatial Economy: Cities, Regions and International Trade. Cambridge, MA: MIT Press.

Golini, A., M. Said, O. Casacchia, C. Reynaud, S. Basso, L. Cassata and M. Crisci (2001). Migration and Urbanization in Ethiopia, with Special Reference to Addis Ababa. Rome: Institute for Population Research - National Research Council.

Gollin, D. (2010). ‘Agricultural Productivity and Economic Growth'. In P. Pingali and R. Evenson (eds), Handbook of Agricultural Economics, Vol. 4. New York: Elsevier.

Haggblade, S., P. Hazell, and J. Brown (1989). 'Farm-nonfarm Linkages in Rural SubSaharan Africa’. World Development, 17(8): 1173-1202.

Hazell, P., C. Poulton, S. Wiggins, and A. Dorward (2010). 'The Future of Small Farms: Trajectories and Policy Priorities’. World Development, 38(10): 1349-61.

Henderson, J. V., and H. G. Wang (2005). 'Aspects of the Rural-Urban Transformation of Countries. Journal of Economic Geography, 5: 23-42.

Johnson, B. F., and J. W. Mellor (1961). 'The Role of Agriculture in Economic Development'. American Economic Review, 51(4): 566-93.

King, R .P., and D. Byerlee (1978). 'Factor Intensities and Locational Linkages of Rural Consumption Patterns in Sierra Leone'. American Journal of Agricultural Economics, 60(2): 197-206.

Lewis, W. A. (1954). 'Economic Development with Unlimited Supplies of Labour'. The Manchester School of Economics and Social Studies, 22(2): 139-91.

Lipton, M. (1980). 'Migration from Rural Areas of Poor Countries: The Impact on Rural Productivity and Income Distribution’. World Development, 8(1): 1-24.

McMillan, M. S., and D. Rodrik (2012). 'Globalization, Structural Change and Productivity Growth’. Washington, DC: International Food Policy Research Institute. Unpublished manuscript.

Ravallion, M., S. Chen, and P. Sangraula (2007). 'New Evidence on the Urbanization of Global Poverty’. Population and Development Review, 33(4): 667-701. 
Ravallion, M., and G. Datt (1996). 'How Important to India's Poor Is the Sectoral Composition of Economic Growth?'. The World Bank Economic Review, 10(1): 125.

Rosenthal, S. S., and W. C. Strange (2004). 'Evidence on the Nature and Sources of Agglomeration Economies'. In J. V. Henderson and J. F. Thisse (eds), Handbook of Regional and Urban Economics, vol. 4. Amsterdam: Elsevier.

Thurlow, J. (2012). 'Kenya'. In X. Diao, J. Thurlow, S. Fan, and S. Benin (2012). Strategies and Priorities for African Agriculture: Economywide Perspectives from Country Studies. Washington, DC: International Food Policy Research Institute.

Thurlow, J., X. Diao, and E. Zhu (2007). A 2005 social accounting matrix (SAM) for Uganda. Washington, DC: International Food Policy Research Institute.

UBOS (Uganda Bureau of Statistics). (2002a). Population and Housing Census 2002. Kampala: Uganda: Republic of Uganda.

UBOS (2002b). Business Inquiry 2001/02. Kampala: Uganda: Republic of Uganda.

UBOS (2006). National Household Survey 2005/06. Kampala: Uganda: Republic of Uganda.

Wiebelt, M., K. Pauw, J. M. Matovu, E. Twimukye, and T. Benson (2011). 'Managing Future Oil Revenues in Uganda for Agricultural Development And Poverty Reduction: A CGE Analysis of Challenges and Options'. Working Paper 1696. Kiel: Kiel Institute for the World Economy.

World Bank (2008). World Development Report 2009: Reshaping Economic Geography. Washington, DC: World Bank.

World Bank (2011). World Development Indicators. Washington, DC: World Bank. 


\section{Appendix: Model specification}

\section{A1 Consumer and producer behaviour}

Representative consumers and producers in our model are treated as individual economic agents. We assume households (consumers) make decisions so as to maximize welfare (utility) subject to a budget constraint. For this we employ a linear expenditure system (LES) of demand:

$$
P_{i} \cdot C_{i a}=P_{i} \cdot \gamma_{i a}+\beta_{i h a} \cdot\left(\frac{\left(1-s_{a}-t d_{a}\right) \cdot Y_{a}}{L S_{a}}-\sum_{i \prime} P_{i \prime} \cdot \gamma_{i \prime a}\right)
$$

where $C$ is per capita consumption of good $i$ in area $a$ (i.e., cities, towns or rural areas), $\gamma$ is a minimum subsistence level, $\beta$ is the marginal budget share, $P$ is the market price of each good, $Y$ is total household income, $L S$ is total labour supply (a proxy for population), and $s$ and $t d$ are savings and direct tax rates, respectively. Our demand functions allow consumption patterns and income elasticities to vary across households in cities, towns and rural areas.

We assume producers maximize profits subject to input and output prices. A constant elasticity of substitution (CES) function determines output quantity $X$ from sector $i$ in area $a$ :

$$
X_{i a}=\alpha_{i a} \cdot\left(\delta_{i a} \cdot L_{i a}^{-\rho_{i a}}+\left(1-\delta_{i a}\right) \cdot K_{i a}^{-\rho_{i a}}\right)^{-1 / \rho_{i a}}
$$

where $\alpha$ reflects total factor productivity (TFP), $L$ and $K$ are labour and capital demands, and $\delta$ and $\rho$ are share and substitution parameters. Our production functions permit technologies to vary across producers and areas. Maximizing profits subject to Equation 2 gives the factor demand equations:

$$
\frac{L_{i a}}{K_{i a}}=\left(\frac{r \cdot D_{i a}}{W_{a}} \cdot \frac{1-\delta_{i a}}{\delta_{i a}}\right)^{1 /\left(1+\rho_{i a}\right)}
$$

where $W$ is the labour wage in area $a$, and $r$ is a fixed economy-wide capital rental rate adjusted by a sector/area-specific distortion term $D$. The factor substitution elasticity is a transformation of $\rho$. Higher elasticities mean producers can more readily substitute between labour and capital when relative prices change. We do not show intermediate demand in the equations, although this is included in our model. The producer price $P X$ is the sum of factor payments per unit of output:

$$
P X_{i a} \cdot X_{i a}=W_{a} \cdot L_{i a}+r \cdot D_{i a} \cdot K_{i a}
$$

\section{A2 National product markets and international trade}

Products are traded in national markets at a single market-clearing price $P$. The national market assumption is needed because internal trade data are unavailable for Ethiopia 
and Uganda. Output from each area is combined into a composite national good $Q$ using a CES function:

$$
Q_{i}=\phi_{i} \cdot\left(\sum_{a} \lambda_{i a} \cdot X_{i a}^{-\tau_{i}}\right)^{-1 / \tau_{i}}
$$

Equation 5 permits imperfect substitution between goods from different areas. Relative producer prices are determined by the following first order condition, derived from minimizing the composite supply price of each good:

$$
P X_{i a}=P_{i} \cdot\left(1-t i_{i}\right) \cdot Q_{i} \cdot\left(\sum_{a \prime} \lambda_{i a^{\prime}} \cdot X_{i a^{\prime}}^{-\tau_{i}}\right)^{-1} \cdot \lambda_{i a} \cdot X_{i a}^{-\tau_{i}-1}
$$

where $t i$ is the indirect tax rate applied to domestic sales. This function implies that demand for an area's output rises when its supply price falls relative to those in other areas.

We do not show the equations governing international trade. However, our model permits two-way trade assuming imperfect substitution between domestic and foreign goods (see Armington 1969). A constant elasticity of transformation (CET) function determines exports and a CES function determines imports. 11 World commodity prices are fixed under a small country assumption. The current account balance is fixed in foreign currency units and the real exchange rate is flexible (i.e., a price index of tradable to non-tradable goods).

\section{A3 Government and investment demand}

Assuming all factors in an area are owned by households in that area, then total income $Y$ is

$$
Y_{a}=\sum_{i}\left(W_{a} \cdot L_{i a}+r \cdot D_{i a} \cdot K_{i a}\right)+h_{a} \cdot L S_{a}
$$

where $h$ is per capita transfer payments from the government. The government is treated as a separate agent. Total domestic revenue is the sum of direct and indirect taxes, as shown on the left-hand side of the following equation:

$$
\sum_{a} t d_{a} \cdot Y_{a}+\sum_{i} t i_{i} \cdot P_{i} \cdot Q_{i}=\sum_{i} P_{i} \cdot A \cdot g_{i}+\sum_{a} h_{a} \cdot L S_{a}+B
$$

The government uses revenues to purchase goods and make transfers (i.e., recurrent spending) and to save (i.e., finance public capital investment). This is shown on the right-hand side of Equation 8. Our macroeconomic closure for the government account assumes that public consumption spending is equal to base-year quantities $g$ multiplied by an exogenous adjustment factor $A$. The fiscal balance $B$ adjusts to equalize total revenues and expenditures.

11 Foreign trade decisions take place in national markets (i.e., export and import relative prices are compared to the price of the composite good produced by cities, towns and rural areas). 
We assume a savings-driven investment closure, i.e., total investment adjusts to the level of savings in the economy. As shown below, a national savings pool finances investment:

$$
\sum_{a} s_{a} \cdot Y_{a}+B=\sum_{i}\left(P_{i} \cdot I \cdot i p_{i}+P_{i} \cdot G \cdot i g_{i}\right)
$$

where ip and ig are fixed base-year quantities of private and public investment, respectively, multiplied by adjustment factors $I$ (endogenous) and $G$ (exogenous). For a given level of savings, an increase in public investment $G$ must be matched by a decline in private investment $I$, i.e., the government 'crowds-out' private investors.

\section{A4 Factor and product market equilibrium}

We assume labour is fully employed. As such, total labour supply $L S$ in each area is fixed and, in equilibrium, must equal the sum of all sector labour demands:

$$
L S_{a}=\sum_{i} L_{i a}
$$

Unlike labour, which is mobile across sectors, capital is sector/area-specific. Both factor demand $K$ and the economy-wide rental rate $r$ are therefore fixed (see Equation 3 ) and the rental rate distortion term $D$ adjusts so that sectoral profit rates equate capital demand and supply.

Finally, product market equilibrium requires that the composite supply of each good $Q$ equals total private and public consumption and investment demand:

$$
Q_{i}=\sum_{a} C_{i a} \cdot L S_{a}+A \cdot g_{i}+I \cdot i p_{i}+G \cdot i g_{i}
$$

Market prices $P$ adjust to ensure equilibrium is achieved. Together, the above 11 equations simultaneously solve for the values of 11 endogenous variables (i.e., $C, X, L$, $D, Q, P X, Y, B, I, W$ and $P$ ). The national consumer price index (CPI) is our numéraire.

\section{A5 Capital accumulation}

Our model is recursive dynamic; i.e., it consists of distinct within- and between-period components. The above equations specify the within-period component. Betweenperiods, exogenous variables and parameters are updated based on externallydetermined trends and previous period results. We describe the processes of capital accumulation, labour migration, and agglomeration and technical change.

While not shown in Equations 1-11, each variable has a time subscript associated with it. Sector-level capital accumulation is determined endogenously based on previous period investment. As shown in Equations 12-14, the quantity of new capital $N$ is based on the value of private investment and the capital price $P K$ (i.e., a composite price derived from investment demand shares ip). New capital is allocated to sectors/areas after applying a national depreciation rate $v$ and according to a capital allocation factor $S K\left(0<S K<1 ; \sum S K=1\right)$ (Dervis, De Melo and Robinson 1982) 


$$
\begin{aligned}
& N_{t}=\sum_{i}\left(P_{i t} \cdot I_{t} \cdot i p_{i}\right) \cdot P K^{-1} \\
& K_{i a t+1}=K_{i a t} \cdot(1-v)+S K_{i a t} \cdot N_{t} \\
& S K_{i a t}=S P_{i a t}+S P_{i a t} \cdot\left(\frac{S R_{i a t}-A R_{t}}{A R_{t}}\right)
\end{aligned}
$$

$S P$ is a sector/area's current share in aggregate profits, $S R$ is a sector/area's profit rate (i.e., $r \cdot D_{i a}$ ), and $A R$ is the national average profit rate. New capital is allocated in proportion to each sector/area's share in aggregate capital income, adjusted by its profit rate relative to the average profit rate. Sectors/areas with above-average profit rates receive a greater share of investible funds than their share in aggregate profits. This 'putty-clay' specification implies that new capital is mobile, but once invested it becomes sector-specific.

\section{A6 Internal labour migration}

Within each period, workers can only migrate across sectors within cities, towns and rural areas. Between periods they can also migrate between areas in response to real wage differentials. The flow of migrants $M$ from area $a$ to $a^{\prime}$ is defined by

$$
M_{a a \prime t}=L S_{a t} \cdot m_{a a} \cdot \frac{W_{a \prime}}{W_{a t}} \cdot c_{a a \prime}
$$

where $m$ is the base-year migration rate and $c$ is a 'compensating wage' (i.e., the inverse of base-year wage differentials). Initially the compensating wage offsets the wage differential leaving the observed migration rate $m$ unchanged, and when applied to total labour supply $L S$, reproduces observed migration flows $M$. If wages in $a^{\prime}$ increase relative to $a$ then the migrant flow increases from base-year levels. Total labour supply is equal to previous period supply multiplied by an exogenous population growth rate $\varepsilon$ and augmented by net migration inflows:

$$
L S_{a t+1}=L S_{a t} \cdot\left(1+\varepsilon_{a}\right)+\sum_{a \prime}\left(M_{a \prime a t}-M_{a a \prime}\right)
$$

While not shown in the equations, our model separates poor and non-poor households within each area. This requires us to track both household populations and factor endowments. Migrant workers are drawn from within-area household groups in proportion to their labour endowments. Workers are assumed to migrate with their families (based on fixed observed dependency ratios), which limits the need to track remittance flows between areas. 12

12 The model captures the benefits of remittances for migrants' dependents that might remain in originating areas. However, remittances to other workers (and their dependents) in the migrant's originating area are not captured. 


\section{A7 Agglomeration, congestion and technical change}

Rates of technical change in each sector/area are determined by three factors (see Equation 17). The first component is the agglomeration effects caused by changes in the density of economic activity. Following Henderson and Wang (2005), agglomeration spillovers are assumed to be a function of population density. Population growth and migrant inflow cause an area's total labour supply $L S$ to expand relative to base-year levels $l s$, and raises TFP in all sectors (i.e., $\alpha$ in Equation 2). Given sparse rural populations and the concentration of industry in urban centres, we only allow agglomeration effects in towns and cities (i.e., $\theta$ is zero for rural areas).

$$
\alpha_{i a t+1}=\alpha_{i a t} \cdot\left(\frac{L S_{a t}}{l s_{a}}\right)^{\theta} \cdot\left(\frac{V_{a t}}{v_{a}}\right)^{\omega} \cdot\left(1+\sigma_{i a}\right)
$$

The second component depends on the concentration of public capital amongst urban residents. TFP expands more rapidly in areas where per capita public capital stocks $V$ are increasing relative to base-year levels $v$. Equation 18 shows how public capital depreciates at the same rate $v$ as private capital and is replenished by exogenouslydetermined public investment. Congestion occurs when, for a given level of investment, an inflow of migrants causes per capita capital stocks $V$ to decline, thereby slowing the rate of technical change.

$$
V_{a t+1}=V_{a t} \cdot(1-v)+\left(\sum_{i} P_{i t} \cdot G_{t} \cdot i g_{i}\right) \cdot P K^{-1} \cdot L S^{-1}
$$

The third determinant of technical change is an exogenous growth rate $\sigma$, which allows the model to track long-term growth trends after accounting for growth in factor supply and endogenous sources of technical change. 